\title{
PTSD in the Context of Malignant Disease
}

\author{
A.M. Tacón \\ Texas Tech University, \\ USA
}

\section{Introduction}

Posttraumatic stress disorder or PTSD is an extreme psycho-physiological response disorder that may occur in individuals who are exposed to a potentially traumatic event that can involve the subjectively profound threat of loss... of life or limb. To receive a PTSD diagnosis, reactions to the catastrophic or traumatic stressor must involve profound fear, helplessness, or horror. Furthermore, such individuals have to experience symptoms from three separate yet co-occurring symptom clusters. These clusters or domains include: 1) intrusive recollections or the re-experiencing of the event with accompanied intense psychological distress or physiologic reactivity; 2) persistent avoidance of activities, thoughts as well as feelings associated with the traumatic event; and, 3) increased or extreme arousal that may include an exaggerated startle response, hypervigilance, or insomnia (American Psychiatric Association, 1994; Uddin et al., 2010) To justify a PTSD diagnosis, symptoms must be present for at least one month, and impair an individual's interpersonal, occupational, or social functioning (American Psychiatric Association, 1994). PTSD has been described as a specific phenotype that develops as the result of a failure to contain the normal stress response (Yehuda \& LeDoux, 2007), resulting in dysregulation of the hypothalamicpituitary-adrenal or HPA axis, a major stress response system of the body that interacts with the immune system to maintain homeostasis (Wong, 2002). PTSD-affected and unaffected individuals have distinct expression patterns in genes involved in immune activation (Segman et al., 2005; Zieke et al., 2007), and in genes that encode neural and endocrine proteins (Segman et al., 2005; Yehuda et al., 2009). Above all, PTSD is both an external and internal experience; that is, PTSD is an external catastrophic or traumatic event and an internal psycho-physiological experience.

\subsection{Trauma goes public}

Once upon a time in the west, PTSD was known as a psychiatric disorder associated most frequently with Vietnam War veterans as exemplified by the label of post-Vietnam syndrome (Friedman, 1981). This, despite the fact that similar war-related traumatic experiences of American soldiers who served in Vietnam can be found as far back as Homer's epic account of Achilles in The Iliad (Shay, 1994). Yet, while long-term psychiatric conditions were witnessed in previous war veterans, PTSD failed to permeate public consciousness until Vietnam. Indeed, Mezey and Robbins point out that PTSD has socio-economic and political implications since veterans are the group most associated with this disorder (2001). With 
Vietnam, PTSD exploded into popular culture, becoming a subject for the general public in many films: Apocalypse Now (1979), Born on the Fourth of July (1989), Casualties of War (1989), The Deer Hunter (1978), First Blood (1982), Full Metal Jacket (1987), Good Morning, Vietnam (1987), the Green Berets (1968), Hamburger Hill (1987), Hanoi Hilton (1987), Jacob's Ladder (1990), the Killing Fields (1984), and Platoon (1986) (Bealle, 1997). In 1980, posttraumatic stress disorder (PTSD) was recognized as an official classification of a psychiatric disorder in the third edition of the Diagnostic and statistical manual of mental disorders (DSM-III) (American Psychiatric Association, 1980). This inclusion of PTSD in DSM-III basically served to legitimize a psychological disorder by re-labeling what had been described in the forgotten past as "soldier's heart," "shell shock," "railway spine, "war neurosis," "traumatic neurosis," "combat trauma," or "combat fatigue" (Bealle, 1997). The growth of psychiatric epidemiology enabled PTSD investigations to include samples of general populations in the United States and in other countries. In the U.S. during the past decade, trauma "goes public" was nowhere more evident than in the aftermath of 9/11 with the attack on the Twin Towers. The public traumatic event of "9/11 changed the picture of PTSD, and transformed it from being simply a mental disorder that psychiatrists deal with to a public health issue;" that is, "for the first time, psychiatric leaders pondered how factors such as media coverage, community cohesion, and poverty may affect the public's mental health when mass disaster strikes" (Brandt, 2011; Schuster et al., 2001).

\section{PTSD in the context of cancer}

The potentially traumatic and protracted nature of cancer's disease course and treatment received acknowledgment in 1994, when the Diagnostic and statistical manual of mental disorders, fourth edition (DSM-IV), revised events that may precede a posttraumatic response. Specifically, "life threatening illness" was added to the criteria as a potentially precipitating event for the development of posttraumatic stress disorder or PTSD (American Psychiatric Association, 1994). Previously, criteria has centered upon acute events such as war, natural disasters, automobile accidents, and rape. This new inclusion of a chronic and possible terminal disease process into the diagnostic criteria, indeed, was a significant change as to precipitating events associated with PTSD. First, diagnostic criteria for PTSD within the context of malignant disease will be summarized. Then, a review of the literature with current PTSD prevalence will follow with prevalence rates for identified cancer types and age groups as adequate data and number of studies permit, risk factors, and lastly, concluding comments.

\subsection{Trauma by any other name}

Before reviewing diagnostic criteria, the debate about malignant illness as a traumatic event needs to be addressed (e.g., Kwekkeboom \& Seng, 2002; Palmer et al., 2004), in order to highlight that variation is not negation of a disorder's existence. Events such as rape, assault, or natural disasters, etc., tend to be singular events restricted to a finite period during which the external agent ceases to be acutely present in real living time. It may be argued that cancer is ambiguous as a stressor event, for malignancy does not fit neatly into an objective timeline with a discrete beginning and ending. One may ask, what event truly was the stressor event? Was it the public confirmation of the diagnosis, of which, one may have 
already decided privately was cancer?... Was it a procedure such as the biopsy?...Was it a treatment regimen? Or was it side effects from treatment or the disease? Regardless, the bottom line is that the threat of death is real and present at all times. Secondly, another variation of the posttraumatic experience related to cancer is the time zone of traumaticinducing reality. Traditional stressor events, which are thus re-experienced, obviously are located in the past, and are primarily retrospective trauma. Cancer-related PTSD, however can be viewed as being bidirectionally traumatic in terms of subjective time: retrospective with memories of the past, yet also prospectively traumatic with a truncated future that is equally as threatening, helpless, and horrifying. The integrity of self is threatened because self is in clear and present---and future danger of not existing. The traumatizing reality that one's long-term plans, hopes or dreams for the future such not seeing a child graduate from high school, get married, etc., or worse---that one will die an agonizing and painful death are forward experiences in the timeline of trauma that personifies a foreshortened future.

Thirdly, another variation of cancer-related PTSD is the fact that the traumazing agent or perpetrator is not external; rather, it is internal in the form of a biological, pathophysiological disease with threat of recurrence, which can lead to a sense of ambivalent betrayal of self. The rude reality is that trauma is experienced in the past, in the present, and in the future tense of experiencing. Moreover, being a cancer survivor does not dispell distress of life-threatening trauma or mean that one is safe and sound. In addition to anxiety and depressive symptomatology, pervading concerns about prognosis, treatment options and effects, or ruminating fears about upcoming doctor appointments and disease recurrence, are all common sources of distress that can plague cancer patients in survivorship long after treatment has ended (Andrykowsk, et al., 2008; Montgomery et al., 2003). For example, acute or sub-acute symptoms may erupt with each doctor's visit, routine check-up, or getting a mammogram, etc., from post-traumatic cues of a patient's previous cancer experience. Unfortunately, routinized triggers can become embedded within the healthcare system, to where a cycle of nosocomial re-triggering or institutional retraumatization is conceivably possible. Indeed, the original traumatic-inducing event may be lost among the chronic cascading triggers---even in the absence of recurrence or a new primary site of malignancy.

The addition of "life threatening" illness to official PTSD criteria is exactly that---lifethreatening. The spontaneous potential of traumatic triggers and the pervasive pain from living a disrupted life with PTSD---be it from a traditional event or a life-threatening illness with recurrence---is equivocal when it comes to human physical and mental suffering. In sum, cancer-related PTSD is no less valid or more ambiguous than traditional stressor events, for trauma by any other name---cancer--- is trauma despite variation of etiology.

\section{DSM in brief: Diagnostic criteria for PTSD}

A brief review of general symptom clusters (see Table 1) (Friedman, 2006) and diagnostic criteria A - F (Table 2) (American Psychiatric Association, 1994, 2000), will be presented with tables to make the information more user-friendly. In order to be diagnosed with PTSD due to the potentially [precipitating] traumatic event of being diagnosed with a malignant disease process, all of the six criteria, that is, A - F, must be satisfied. 


\begin{tabular}{|c|c|}
\hline Cluster & Specific Symptoms \\
\hline Reexperiencing & $\begin{array}{l}\text { - Intrusive recollections } \\
\text { - Traumatic nightmares } \\
\text { - } \text { Flashbacks } \\
\text { - Trauma-evoked psychological distress } \\
\text { - Trauma-evoked physiological reactions }\end{array}$ \\
\hline Avoidant/Numbing & $\begin{array}{ll}\text { - } & \text { Avoiding trauma-related } \\
\text { thoughts/feelings } \\
\text { - } & \text { Avoiding trauma-related } \\
\text { - } & \text { activities/places/people } \\
\text { - } & \text { Diminisished interest } \\
\text { - } & \text { Detached or estranged feelings } \\
\text { - } & \text { Restricted range of affect } \\
\text { - } & \text { Sense of foreshortened future }\end{array}$ \\
\hline Hyperarousal & $\begin{array}{ll}\text { - } & \text { Insomnia } \\
\text { - } & \text { Irritability } \\
\text { - } & \text { Difficulty in focusing/concentrating } \\
\text { - } & \text { Hypervigilance } \\
\text { - } & \text { Exaggerated startle reaction }\end{array}$ \\
\hline
\end{tabular}

Table 1. Symptom Clusters for PTSD (Friedman, 2006)

\begin{tabular}{|l|l|}
\hline Criterion A: Stressor & Exposed to a traumatic event in which both of the \\
& following were present: \\
A1. Person experienced, witnessed or was \\
confronted by an event that involved actual or \\
threatened death or serious injury, or a threat to \\
the physical integrity of self or others. The \\
traumatic event includes diagnosis of a life- \\
threatening illness such as cancer that threatened \\
one's life and/or physical integrity; involved \\
either direct personal experience (such as being \\
the patient) witnessing, confronting, or learning \\
about the illness experience through a family \\
member or close friend - which may pose a threat \\
& to the integrity of a significant other \\
A.2 Response involved intense fear, helplessness \\
or horror
\end{tabular}




\begin{tabular}{|c|c|}
\hline & $\begin{array}{l}\text { B2. Recurrent distressing dreams of the event } \\
\text { B3. Acting or feeling as if the traumatic event were } \\
\text { recurring with sense of re-experiencing it again; } \\
\text { dissociative flashbacks } \\
\text { B4. Intense psychological distress at exposure to } \\
\text { internal or external cues that symbolize or } \\
\text { resemble an aspect of the traumatic event } \\
\text { B5. Physiological reactivity at exposure to } \\
\text { internal/external cues that symbolize or resemble } \\
\text { an aspect of traumatic event }\end{array}$ \\
\hline Criterion C: Avoidant/Numbing & $\begin{array}{l}\text { Persistent avoidance of stimuli associated with the } \\
\text { trauma and numbing of general responsiveness } \\
\text { (not present before the trauma, in this case, } \\
\text { cancer) as indicated by three or more of the } \\
\text { following: } \\
\text { C1. Efforts to avoid thoughts, feelings, or } \\
\text { conversations associated with the trauma } \\
\text { C2. Efforts to avoid activities, places or people } \\
\text { that arouse recollections of the trauma } \\
\text { C3. Inability to recall an important aspect of the } \\
\text { trauma } \\
\text { C4. Markedly diminished interest or participation } \\
\text { in significant activities } \\
\text { C5. Feeling of detachment or estrangement from } \\
\text { others } \\
\text { C6. Restricted range of affect (for example, unable } \\
\text { to have loving feelings) } \\
\text { C7. Sense of a foreshortened future, (does not } \\
\text { expect to have a career, children, marriage, or a } \\
\text { normal lifespan }\end{array}$ \\
\hline Criterion D: Hyperarousal & $\begin{array}{l}\text { Persistent symptoms of increased arousal (not } \\
\text { present before the trauma, in this case, cancer) as } \\
\text { indicated by two or more of the following: } \\
\text { D1. Difficulty falling or staying asleep } \\
\text { D2. Irritability or outbursts of anger } \\
\text { D3. Difficulty concentrating } \\
\text { D4. Hypervigilance } \\
\text { D5. Exaggerated startle response }\end{array}$ \\
\hline Criterion E: Duration & $\begin{array}{l}\text { Duration of the disturbance (symptoms in B, C, \& } \\
\text { D) is more than one month. }\end{array}$ \\
\hline Criterion F: Functional Significance & $\begin{array}{l}\text { The disturbance causes clinically significant } \\
\text { distress or impairment in social, occupational or } \\
\text { other important areas of functioning. }\end{array}$ \\
\hline
\end{tabular}

Table 2. DSM Criteria for PTSD (American Psychiatric Association, 1994, 2000) 


\subsection{Criteria A - C}

The DSM's first criterion, A, relates to PTSD's conceptualization as a stress-related response syndrome where the person experienced an event that threatened his/her life or physical integrity (American Psychiatric Association, 1994, 2000). Also, this criterion includes vicarious traumatization, that is, the witnessing of traumatic events as well as hearing traumatic news or unexpected occurrences about loved ones. For example, related PTSD investigations have expanded to include not only the patients themselves, but also, loved ones affected by the experience of cancer in another, for example, parents of children diagnosed with malignancy as well as partners, siblings or significant friends of cancer patients (e.g., Alderfer et al., 2010; Poder, Ljungman, \& von Essen, 2008).

Criterion $\mathrm{B}$ involves persistent re-experiencing of the cancer experience (including the intrusive thoughts of symptoms, the way diagnosis was communicated, impending death or experience of review visits), for example, recurrent and intrusive memories or images in the form of flashbacks or nightmares. Noticeable physical reactions may present, such as breaking out in a sweat, feeling light-headed or nauseous, having palpitations, or breathing gets fast and shallow. Criterion $C$ is persistent avoidant or emotional numbing strategies that serve the purpose of blocking internal or external stimuli reminiscent of the traumatic event, such as avoiding certain people, places, or perhaps even the music playing in the background when the event was occurring.

\subsection{Criteria D - F}

Criterion D involves persistent hyper-physiological arousal and-or anxiousness that were not present before the diagnosis or experience of cancer, and might include sleeping problems, irritability and anger outbursts. Another form of arousal unique to cancer-related PTSD is body symptom hypervigilance or being on guard for signs of another tumor. Criterion E indicates that the duration of such symptoms has persisted for a period of at least one month following the cancer-related traumatic event (e.g., being told the diagnosis or given a poor prognosis, etc.), thereby, distinguishing it from acute stress disorder. Finally, Criterion F indicates the extent to which the symptoms impair domains of life functioning, for example, relational or occupational. Please refer to Table 2.

\section{PTSD and adult cancer}

In general, assessing prevalence rates of PTSD in adults with cancer have consisted primarily of breast cancer patients including a wide range of time between diagnosis and treatment, from several days to over a decade.

\subsection{Current search strategy}

For the current investigation, a literature search was conducted for PTSD prevalence rates in current adult cancer patients and cancer survivors via the ISI Web of Knowledge, Medline and PsycINFO databases, and the references of retrieved articles. The search considered only studies published in English. The main search terms were posttraumatic, PTSD, cancer, cancer patients, prevalence, prevalence rates, in various combinations as needed. The search strategy consisted of several levels of filtering out articles not relevant to the purposes here. The articles considered useful for the aim of this paper included studies where current prevalence rates for PTSD were ssessed, and identification of posttraumatic cases were 
based on official DSM guidelines, that is, DSM criteria had been applied. Also included were studies where participants were current patients at the time of data collection or were cancer survivors of 60 months (the five-year marker) or less since the end of treatment; this was done in an effort to reduce the potential wide range of survivor time variation (i.e., survivors of 13-years, 2-years, etc). No limitations were placed on the number of participants, the study design, or whether a control group was included; studies reporting qualitative data were excluded.

\subsection{Results}

A total of 11 studies met criteria, which were based on interview data collection (See Table 3). The current PTSD diagnostic gold standard remains a clinical interview that is based on the predefined criteria in the DSM (American Psychiatric Association, 1994).Three of the studies involve participants with a mixture of cancer diagnoses excluding breast malignancy (Akechi et al., 2004; Kangas et al., 2005; Widows et al., 2000). The remaining eight studies investigating adult cancer-related PTSD include breast cancer patients at various points in the disease process (Andrykowski et al., 1998; Gandubert et al., 2009; Green et al., 1998; Luecken et al., 2004; Mehnert \& Koch, 2007; Mundy et al., 2000; Okamura et al., 2005; Shelby et al., 2008). Despite advances in breast cancer diagnosis and treatments, it remains a monumental stressor in these women's lives that continues to elicit greater distress than any other medical diagnosis (Shapiro et al., 2001). This distress is now recognized as an integral component of a patient's clinical presentation (Bultz \& Carlson, 2006); additionally, depression, anxiety, and posttraumatic stress disorder (PTSD) symptoms occur somewhere between 20 and $66 \%$ of women in the first 12 months alone after their diagnosis (Burgess et al., 2005; Vos et al., 2004). Such psychological difficulties in response to the challenge of cancer appear congruent with certain pre-cancer factors that may set the stage for patient vulnerability. Specifically, posttraumatic stress disorder cases have been found to be distinguished by a previous history of violent traumas as well as psychological problems such as anxiety disorders that predate the diagnosis of cancer (e.g., Shelby et al., 2008).

The sample sizes in the eight breast cancer studies range from 37 to 160 participants with a mean of 93 participants and the median of 78 participants. Prevalence rates for current cancer-related PTSD range from $0 \%$ to $16.2 \%$ with a mean of $4.6 \%$ and a median of $2.75 \%$. Sample sizes for the three studies of mixed cancer types range from 82 to 209; the mean of participants in these studies is 131 participants with a median of 102 participants. The prevalence rates for current cancer-related PTSD in these studies range from $0 \%$ to $22 \%$ with a mean prevalence rate of $9 \%$ and a median of $5 \%$.

In sum, these findings are congruent with previous estimates of current cancer-related PTSD prevalence in adult patients, that is, in women with breast cancer or mixed samples of gender with head, neck or lung cancer ranging from 0 to 32\% (Hamann et al., 2005). Several points need to be acknowledged. First, the majority of studies---as tends to be the case in the area of psychosocial oncology literature---involved women with breast cancer. Thus, most of the current knowledge regarding PTSD in the context of malignant disease is based upon this cancer population with frequently low sample sizes. Basically, this means that caution is needed, for generalizability of such results do not apply to other disease populations or to those with other types of cancer. Also, the majority of these investigations were crosssectional studies with time variation as to time of assessment from either diagnosis or 
treatment. Cross-sectional data prohibits clinical understanding of the development as well as the trajectory patterns of PTSD in those with cancer. The relative lack of prospective or longitudinal data is needed to inform clinicians early in the disease process so that highly distressed patients may be identified and helped as early as possible with this lifethreatening illness. Lastly, cross-sectional research does little in the way of determining risk factors relevant to later survival time or predicting the delayed onset of posttraumatic stress. Attention now turns to investigations assessing PTSD in strictly male samples with diagnosed malignancy.

\begin{tabular}{|c|c|c|c|c|}
\hline Study & Design & Sample & Time Period & \begin{tabular}{|l|} 
PTSD \\
Prevalence
\end{tabular} \\
\hline $\begin{array}{l}\text { Akechi } \\
\text { et al. (2004) }\end{array}$ & $\begin{array}{l}\text { Cross- } \\
\text { sectional }\end{array}$ & $\begin{array}{l}\mathrm{n}=209 ; \text { males } / \\
\text { females; mixed } \\
\text { cancer diagnosis }\end{array}$ & $\begin{array}{l}25 \text { months post- } \\
d x\end{array}$ & $\begin{array}{l}0 \% \text { (only } 100 \\
\text { participants } \\
\text { assessed) }\end{array}$ \\
\hline $\begin{array}{l}\text { Andrykowski } \\
\text { et al., (1998) }\end{array}$ & $\begin{array}{l}\text { Cross- } \\
\text { sectional }\end{array}$ & $\mathrm{n}=82$ females; breast & $\begin{array}{l}37 \text { months post- } \\
\text { treat }\end{array}$ & $6 \%$ current \\
\hline $\begin{array}{l}\text { Gandubert } \\
\text { et al., (2009) }\end{array}$ & $\begin{array}{l}\text { Cross- } \\
\text { sectional }\end{array}$ & $\mathrm{n}=144 ;$ female; breas & $1-3$ years post- $\mathrm{dx}$ & $4.9 \%$ current \\
\hline $\begin{array}{l}\text { Green } \\
\text { et al., (1998) }\end{array}$ & $\begin{array}{l}\text { Cross- } \\
\text { sectional }\end{array}$ & $\begin{array}{l}\mathrm{n}=160 \text { females; } \\
\text { breast }\end{array}$ & $\begin{array}{l}6.5 \text { months post- } \\
\text { treat }\end{array}$ & $2.5 \%$ current \\
\hline $\begin{array}{l}\text { Kangas } \\
\text { et al., (2005) }\end{array}$ & Longitudinal & $\begin{array}{l}\mathrm{n}=82 ; \\
\text { males/females head, } \\
\text { neck, lung cancer }\end{array}$ & 6 months post- $\mathrm{dx}$ & $22 \%$ current \\
\hline $\begin{array}{l}\text { Luecken } \\
\text { et al., (2004) }\end{array}$ & $\begin{array}{l}\text { Cross- } \\
\text { sectional }\end{array}$ & $\begin{array}{l}\mathrm{n}=71 ; \\
\text { females; breast }\end{array}$ & $\begin{array}{l}\text { 1-6 months post- } \\
\mathrm{dx}\end{array}$ & $3 \%$ current \\
\hline $\begin{array}{l}\text { Mehnert \& } \\
\text { Koch, (2007) }\end{array}$ & $\begin{array}{l}\text { Cross- } \\
\text { sectional }\end{array}$ & $\begin{array}{l}\mathrm{n}=127 ; \\
\text { females; breast }\end{array}$ & $\begin{array}{l}15 \text { days post-dx } \\
\text { of initial cancer } \\
(77 \%) ; \\
\text { or recurrent } \\
\text { malignancy } \\
(23 \%), 0-67 \text { days }\end{array}$ & $2.4 \%$ current \\
\hline $\begin{array}{l}\text { Mundy } \\
\text { et al., (2000) }\end{array}$ & $\begin{array}{l}\text { Cross- } \\
\text { sectional }\end{array}$ & $\begin{array}{l}\mathrm{n}=37 ; \\
\text { females; breast }\end{array}$ & $>100$ days post-tx & $0 \%$ current \\
\hline $\begin{array}{l}\text { Okamura } \\
\text { et al., (2005) }\end{array}$ & $\begin{array}{l}\text { Cross- } \\
\text { sectional }\end{array}$ & $\begin{array}{l}\mathrm{n}=50 ; \text { females; } \\
\text { breast recurrence }\end{array}$ & $\begin{array}{l}\text { 1-6 months post- } \\
\mathrm{dx} \text { recurrence }\end{array}$ & $2 \%$ current \\
\hline $\begin{array}{l}\text { Shelby } \\
\text { et al., (2008) }\end{array}$ & Longitudinal & $\begin{array}{l}\mathrm{n}=74 ; \\
\text { females; breast }\end{array}$ & $\begin{array}{l}\mathrm{dx} / \text { surgery }-18 \\
\text { months }\end{array}$ & $1.6 \%$ current \\
\hline $\begin{array}{l}\text { Widows } \\
\text { et al., (2000) }\end{array}$ & $\begin{array}{l}\text { Cross- } \\
\text { sectional }\end{array}$ & $\begin{array}{l}\mathrm{n}=102 ; \\
\text { males/females; } \\
\text { cancer not specified }\end{array}$ & $\begin{array}{l}20.4 \text { month post- } \\
\text { bone marrow } \\
\text { transplant }\end{array}$ & $5 \%$ current \\
\hline
\end{tabular}

Table 3. Summary of select cancer studies

\section{PTSD: Men with malignant disease}

While a plethora of studies have assessed prevalence rates for women breast cancer and/or mixed gender studies, a paucity of research exists as to the prevalence rates in strictly male 
samples with malignant processes. This is surprising since survivors of prostate cancer continue to grow as well as the fact that psychological distress in response to receiving a prostate cancer diagnosis is a recognized phenomenon (Anastasiou et al., 2011; Gwede et al., 2005; Namiki et al., 2007). Furthermore, psychological distress in prostate cancer patients has been found to be related to the following: stage of disease, shorter time since diagnosis, and treatment options or decisions (Gwede et al., 2005). For men, receiving the diagnosis of malignant disease has been found to be associated with responses that include anxiety, denial or distress (Kronenwetter et al., 2005).

Distress related to decision-making is a common experience among men after the diagnosis of prostate cancer; specifically, reports indicate that around $63 \%$ report high decision-related distress persisting the first year after treatment for $42 \%$ of all men (Steginga et al., 2008). Also, an increased manifestation of traumatic stress symptoms has been found in some cases of newly diagnosed men with localized prostate cancer before the beginning of treatment (Bisson, 2007); on the other hand, low emotional distress has been documented as being present even 2 years after a radical prostatectomy (Perez et al., 2002). Follow-up of males during the disease course of their prostate cancer show that males with prostate cancer may suffer with long-term physical and psychological consequences---to the point of affecting their quality of life (Penson, 2007; Sanda et al., 2008). Indeed, accumulating data within the past 15 years has produced a body of literature investigating health related quality of life (HRQOL) outcomes pertaining to localized prostate cancer (Penson, 2007). This stands in contrast to empirical exploration regarding adjustment in such male cancer survivors. Unfortunately, the literature does not demonstrate ample descriptive investigations as to the course of psychological adjustment for men who have been diagnosed with and treated for prostate cancer (Steginga et al., 2004). No studies could be identified that specifically assessed PTSD in men with testicular or lung cancer.

A recent study by Anastasiou and colleagues (2011), believed to be the only study that has focused on investigating the presence of acute posttraumatic stress disorder (PTSD) in men with malignant disease necessitating a radical prostatectomy, assessed symptoms in 15 men one month after surgery. The men completed the Davidson Trauma Scale rather than being assessed by interview. Analyses determined that $26.7 \%$ of the men's scores met scale criteria for acute PTSD, which was found to be independent of the patient's educational level. In sum, despite the fact that prostate cancer is the second most frequently diagnosed cancer in developed countries, and the third most common cause of death in men (Damber \& Aus, 2008), little is known about the psychological ramifications for prostate cancer patients after surgery (Burns \& Mahalik, 2008; Namiki et al., 2007; Steginga et al., 2004).

\section{PTSD and pediatric cancer}

The present search revealed few reports of cancer-related PTSD in pediatric patients.

\subsection{Results}

The search revealed only two studies assessed within the five-year mark with data regarding cancer-related PTSD (Landolt et al.,1998; Pelcovitz et al., 1998). However, due to the lack of studies, a third study that assessed PTSD at 5.3 years, was included (Kazak et al., 2004). The participants were less than 18 years of age at the time of these investigations, which all consisted of mixed cancer diagnoses. The sample sizes were 150, 7, and 23; the mean sample size was 60 with a median of 23 participants. The prevalence rates in these 
studies for current cancer-related PTSD were documented as ranging from $4.7 \%$ to $71 \%$; the mean prevalence rate was $31 \%$ with a median of $17 \%$. It must be pointed out that the prevalence rate finding of $71 \%$ comes from a study with a small sample size of only seven participants who were identified as "newly diagnosed." Therefore, the possibility that this assessment may have occurred within the first month of diagnosis calls into question the appropriateness and validity of these data. Unfortunately, the small number of studies in this area of current PTSD prevalence as well as the questionable data provided limit the scope of this review; therefore, conclusions about prevalence rates in this population are prohibitive at this time.

\section{PTSD: All in the family}

Each year in the United States, approximately 14,000 children are diagnosed with cancer (Ries et al., 2008). The diagnosis of cancer is a traumatic experience for both the child and the family, which understandably causes a great of deal of disruption within the family system. The following review will encompass literature regarding posttraumatic stress among 1) parents of children with cancer, 2) the bereaved following the death of a cancer patient, and 3) the siblings of children diagnosed with cancer.

\subsection{Parent and child}

Having a child diagnosed with cancer is one of the most severe stressors that parents could possibly ever experience; the threat of their child's death and feelings of helplessness converge as the entire family faces the uncontrollable enemy of cancer (Kazak, 1998; Patterson et al., 2004). The change of the A1 event criterion of PTSD in the DSM-IV (American Psychiatric Association, 1994) to include "the diagnosis of a life threatening disease" as potentially traumatizing, expanded the range of traumatic effects to include the patient's interpersonal domain. Consequently, an individual's witnessing of or learning about a significant person [to him/her] being diagnosed with a terminal illness is now viewed as potentially traumatizing. Family members and loved ones torturously stand by as their beloved endures periods of devastating illness effects, physical and psycho-spiritual pain, or highly invasive treatments that produce debilitating fatigue---all of which may be followed by uncertain terminal illness and possible death. Family members typically are involved in making hard calls or decisions regarding the patient, which, in itself, is a potential independent risk factor for PTSD (Azoulay et al., 2004, 2005).

The psychological sequelae of childhood cancer in both the children and their parents are well documented, which consists of post-traumatic stress symptoms, anxiety, and depression (Kazak, 2005; Kazak et al., 2005). More specifically, the sequelae as to parental risk for affective and stress reactions range from $9 \%$ to $40 \%$ for the above disorders for a period of up to 3 years after the child's diagnosis (Kazak et al., 2004; Stoppelbein \& Greening, 2007). Barakat and colleagues found that the parents of childhood cancer survivors showed significantly higher levels of post-traumatic stress symptoms (PTSS) than a comparison group of parents (1997). Similarly, Kazak found significant elevation in PTSD scores in parents of survivors in contrast to parents of never-ill children (Kazak et al., 1997). Indeed, the line of research exploring distress in relatives of cancer survivors indicate that the relatives are usually at least as distressed as the cancer survivors (especially mothers)---if not more so (e.g., Couper et al., 2006; Mosher \& Danoff-Burg, 2004; Tuinmann et al., 2004). Kazak and colleagues (2004) found current PTSD prevalence for parents of adolescent 
survivors to be $13.7 \%$ for mothers and $9.6 \%$ for fathers. Lastly, an interesting finding in the literature demonstrating the parent-child relationship is that the ill child's psychological adjustment to his/her cancer diagnosis and treatment is highly correlated with the parents' adjustment to their child's diagnosis and treatment (Ljungman et al., 2003).

\subsection{The bereaved}

It has been estimated that for every person that dies five close friends or family members are affected (Zisook et al., 1998), therefore, the bereaved family and friends of cancer patients are at risk of developing psychological traumatic disorders as well as complicated grief. Indeed, the existing PTSD literature for the most part ignores bereaved individuals despite the fact that such individuals meet the A1 stressor criterion of the DSM (American Psychiatric Association, 1994). One of the few studies in this area investigated pre- and postloss bereavement levels of posttraumatic stress symptoms (intrusion and avoidance) in 50 partners of women with metastatic/recurrent breast cancer as well as the relationship of these symptoms to past, current, and anticipatory stressors (Butler et al., 2005). The data indicated that 17 (34\%) of the bereaved partners experienced clinically

significant PTS symptom levels prior to the patients' deaths; specifically, prior to loss, partners' symptoms were positively associated with their current level of perceived stress and anticipated impact of the loss. However, following the death of the loved one, partners' posttraumatic stress symptoms were predicted by higher pre-loss levels of symptoms, past family deaths, and anticipated impact of the loss.

A more recent study investigated PTSD and PTSD predictors in bereaved individuals who had experienced the loss of a close relative to cancer and were attending counseling (Elklit et al., 2010). A total of 251 bereaved relatives, with ages ranging from 14 to $76(\mathrm{M}=41.3)$, were recruited at a counseling service that assisted cancer patients and their relatives. The findings indicated that the prevalence of current PTSD was $40 \%$ in this sample. Furthermore, hierarchical logistic regression analysis showed that the following variables moderated the risk for PTSD: full-time employment, perceived control, and a secure attachment style. An extended period of caretaking as well as high levels of somatization and dissociation also were associated with an increased risk of PTSD (Elklit et al., 2010).

\subsection{The forgotten children: Siblings}

As parents become distressed over the condition of their child diagnosed with cancer, they likely will spend extended periods of time at home or in the hospital attending to the needs of that child. As the stress of the malignant disease process takes its biopsychosocial toll on the child and the parents, the time will come, undoubtedly, when the adults will not be able to physically and emotionally meet the needs of their other children in the family (Alderfer \& Kazak, 2006). It is not surprising, then, that the siblings of children with cancer become increasingly at risk for affective, behavioral, and school problems (Aldelfer \& Hodges, 2010; Alderfer et al., 2010). Siblings of children with cancer experience feelings of anger, fear, grief, guilt, helplessness, insecurity, jealousy, loneliness, loss, resentment, and shock, (e.g., McGrath, 2001; Nolbris et al., 2007; Woodgate, 2006). Furthermore, investigations examining sibling distress increasingly indicate that a marked subset of siblings with a brother or a sister with cancer display post-traumatic stress (PTS) symptoms.

One study investigated whether 78 adolescent siblings of childhood cancer survivors experience posttraumatic stress; the participants completed self-report measures of anxiety, 
perceptions of the cancer experience, and posttraumatic stress (Alderfer et al., 2003). The findings showed that close to half of the sample (49\%) reported mild posttraumatic stress, and more worrisome, that $32 \%$ indicated moderate to severe levels. Additionally, one-fourth of the siblings thought their brother/sister would die just during cancer treatment alone, and more than half of the sample viewed the experience of cancer as scary. These perceptions, not surprisingly, were found to be related to PTS. These siblings reported a greater number of PTS symptoms than did an adolescent comparison group who were not psychologically affected by their sibling's illness, yet did report similar levels of general anxiety. Overall, studies that have investigated PTS reactions in siblings of children with cancer estimate that between $29-38 \%$ of the siblings exhibit moderate to severe cancerrelated PTS---which can occur years after the treatment for cancer has ended (Alderfer et al., 2003; Packman et al., 2004).

\section{Risk factors for cancer - Related PTSD}

Many of the risk factors associated with adult cancer-related PTSD mirror the risk factors for PTSD from other traumas such as combat (e.g., Foy et al., 1987). Incidence and severity of cancer-related PTSD are affected by factors that occur before and during the cancer experience (Gurevich et al., 2002).

\subsection{Gender, age, and socio-economic status}

Pre-cancer factors, for example, gender, age, socio-economic status, and trauma history are associated with cancer-related PTSD. In terms of gender, female patients appear to be at greater risk for developing PTSD than their male counterparts (Kangas et al., 2002). Younger age at diagnosis also is a potential risk factor (Epping-Jordan et al., 1999; Kangas et al., 2002). Specifically, younger women may experience more distress due to the perception that cancer is more threatening to their lives; older women who have lived out the majority of their lifespan, on the other hand, may be less worried about recurrence, and thus display more positive mental adjustment (Glanz \& Lerman, 1992). Socio-economic circumstances, specifically, lower income has been found to be associated with developing cancer-related PTSD; that is, it may be the case that fewer material resources combined with the stress of a cancer diagnosis may make the cancer experience more traumatic (Cordova et al., 1995).

\subsection{Personality, history, and disease characteristics}

Personality characteristics/traits such as neuroticism, pessimism, a pre-cancer history of affective disorders such as depression, or having a history of traumatic experiences may increase a patient's vulnerability to developing PTSD in the context of cancer (Andrykowski \& Cordova, 1998; Epping-Jordan et al., 1999; Glanz \& Lerman, 1992). Ineffective and maladaptive coping strategies, for example, staunch avoidance regarding the diagnosis of cancer as well as a pre-cancer coping style of avoidance, have been linked with PTSD relating to cancer (e.g., Butler et al., 1999; Jacobsen et al., 2002). It is reasonable to expect that characteristics of the disease process, itself, may contribute to distress and suffering in the form of PTSD. Specifically, research shows that, indeed, risk increases for PTSD in the case of malignant recurrence or the more advanced the stage of the disease (e.g., Andrykowski \& Cordova, 1998). Additionally, research suggests a greater likelihood of patients developing cancer-related PTSD when more aggressive or invasive treatments are used (Gurevich et al., 2002). 


\subsection{Social support}

In 1979, Berkman and Syme published their seminal study linking social relationships to mortality. Three decades later, reliable links between social support and better physical health outcomes continue to be demonstrated, with epidemiological studies showing that those with low levels of social support have higher rates of mortality (Berkman et al., 2000; Uchino, 2004). Moreover, research indicates that social support is associated with improved immune function (e.g., Dixon et al., 2001; Lutgendorf et al., 2005). Thus, the possibility that social factors may be related to certain patients manifesting PTSD during the distress of cancer is congruent with this literature. Data have shown social support to be inversely associated with intrusive thoughts (DSM criterion B) and avoidance of cancer reminders of the cancer experience (DSM criterion C) (Andrykowski \& Cordova, 1998; Jacobsen et al., 2002). In women with metastatic breast cancer, the size of a woman's emotional support network was found to predict avoidant symptoms in the patient (Butler et al., 1999). In terms of relational quality, a salient aspect of significant others in our lives is that of being supportive during times of personal disclosure, that is, the sharing of intimate information with trusted others. In the context of cancer, negative responses from others after a patient disclosed concerns and fears about her disease have been found to be associated with greater PTSD symptomatology (Cordova et al., 2001).

The issue of quality of life is a major line of research in cancer populations. A study by Lewis and colleagues (2001) investigated the moderating effect of social support on the relationship between cancer-related intrusive thoughts and quality of life. Sixty-four breast cancer survivors (of unspecified time since diagnosis or treatment) completed self-report measures of: social support (disclosure of thoughts/feelings to significant others); cancerrelated intrusive thoughts; and, quality of life. After controlling for demographic and treatment variables, the appraised level of social support was found to moderate the negative impact of cancer-related intrusive thoughts on both physical and psychological quality of life measures. Specifically, no significant relationship was found for cancer-related intrusive thoughts and quality of life in women who had endorsed high levels of social support. For women with low levels of perceived support, however, the data revealed a significant and negative relationship between cancer-related intrusive thoughts and participants' quality of life. These data suggest that appraised levels of social support in breast cancer patients may mitigate the impact of traumatic events during a woman's distressing breast cancer experience (Lewis et al., 2001). In sum, research indicates that certain demographic, personal and/or historical characteristics as well as biopsychosocial factors contribute to the multifactorial process of a cancer patient's experience. Data support the notion also that multiple factors appear to influence individual vulnerability and manifestation of posttraumatic symptoms in cancer patients.

\section{Conclusion}

Overall, findings regarding adult prevalence rates in adults with breast and mixed gender/mixed cancer types are consistent with previous estimates of current cancer-related PTSD prevalence in adult patients, that is, rates ranging from 0 to 32\% (Hamann et al., 2005). Several points were highlighted. First, eight of the 11 studies identified in the summary review and listed in Table 3 involved women with breast cancer. Consequently, most of the present state of knowledge about PTSD in cancer patients is based upon this cancer population. Generalizability to other disease populations or to individuals diagnosed with 
different types of cancer thus is limited. Additionally, all but two of the investigations were cross-sectional studies with variance regarding time from either diagnosis or treatment to the study when the assessments occurred. Cross-sectional data limits clinical usefulness and understanding about the trajectory patterns of PTSD in those with cancer; future studies that are prospective or longitudinal in design with large sample sizes are recommended. These findings stand in contrast to the surprising stark paucity of research as to psychological adjustment such as PTSD and risk or predictive factors in men with prostate cancer who end up needing a prostatectomy. Much more research in the future is needed imperatively in this area to fill this gap in the literature. Similarly, further research investigating PTSD and related factors with large sample sizes in pediatric populations are suggested.

Over the past decade, increasing empirical evidence indicates that having a child diagnosed with a malignant disease process is psychologically traumatic for the parents. Specifically, symptoms of PTSD---the reexperiencing of traumatic events, physiologic arousal, and behaviors to avoid cues related to the cancer experience---have been documented in parents (especially mothers), whose children had completed cancer treatment (e.g., Brown et al., 2004; Manne et al., 2004). One study involving 150 families of adolescent childhood cancer survivors 1 to 10 years after completing cancer treatment found that practically all of the families (99\%) had at least one parent who met PTSD symptom criteria for reexperiencing (Kazak et al., 2004). Moreover, $20 \%$ of the families were found to have at least one parent who met criteria for being diagnosed with current PTSD.

Research into posttraumatic stress in the bereaved and siblings of children with cancer were reviewed, with limited quantity and quality of studies noted. Large-scale epidemiological studies are needed to comprehensively estimate prevalence rates of posttraumatic stress for these emerging, psychologically affected populations. A severe absence of investigation exists regarding PTSD among the bereaved of a cancer patient, and adequate estimates of prevalence do not exist at this time. It must be emphasized that the absence of sufficient data in certain types of cancer populations---such as males with prostate cancer, the bereaved or sibling groups---limits intervention approaches and clinical efficacy. A plethora of welldesigned studies ultimately will enable targeted and successful interventions for those suffering with cancer-related PTSD. Only then, will clinical care truly be capable of providing the needed services for those traumatically affected by cancer. Members of the significant family-and-friends system need not struggle helplessly as they live with and function in the context of a "life-threatening" malignant illness.

In closing, future investigations are needed in order to develop targeted, effective and appropriate psychological interventions to address PTSD in cancer patients as well as to educate them about coping with life in the context of cancer. This will be especially salient in the future, based on current philosophical and medical zeitgeist, as the number of cancer survivors continues to increase.

\section{References}

Akechi, T., Okuyama, T., Sugawara, Y., Nakano, T., Shima, Y., \& Uchitomi, Y. (2004). Major depression, adjustment disorders, and post-traumatic stress disorder in terminally ill cancer patients: associated and predictive factors. Journal of Clinical Oncology, 22(10), pp. 1957-1965.

Alderfer, M., \& Hodges, J. (2010). Supporting siblings of children with cancer: A need for family-school partnerships. School Mental Health, 2, pp. 72-81. 
Alderfer, M., \& Kazak, A. (2006). Family issues when a child is on treatment for cancer. In: Comprehensive handbook of childhood cancer and sickle cell disease: A biopsychosocial approach, R.T. Brown, (Ed.), pp. 53-74, Oxford, New York.

Alderfer, M., Labay, L., \& Kazak, A. (2003). Brief report: Does posttraumatic stress apply to siblings of childhood cancer survivors? Journal of Pediatric Psychology, 28, 281-286.

Alderfer, M., Long, K., Lown, E., Marsland, A., Osrowski, N., Hock, J., \& Ewing, L. (2010). Psychosocial adjustment of siblings of children with cancer: a systematic review. Psychooncology, 19, pp. 789-805.

American Psychiatric Association. (1980). Diagnostic and statistical manual of mental disorders: DSM-III, $3^{\text {rd }}$ ed. Author, Washington, DC.

American Psychiatric Association. (1994). Diagnostic and statistical manual of mental disorders (4th ed.). Author, Washington, DC:

American Psychiatric Association. (2000). Diagnostic and statistical manual of mental disorders: (4th ed., text revision). Author, Washington, DC.

Anastasiou, I., Yiannopoulou, K.G., Mihalakis, A., Hatziandonakis, N., Constantinides, C., Papageorgiou, C., \&Mitropoulos, D. (2011). Symptoms of acute posttraumatic stress disorder in prostate cancer patients following radical prostatectomy. American Journal of Men's Health, 5(1), pp. 84-89.

Andrykowski, M. A., \& Cordova, M. J. (1998). Factors associated with PTSD symptoms following treatment for breast cancer: Test of the Andersen model. Journal of Traumatic Stress, 11, pp. 189-203.

Andrykowski, M.A., Cordova, M.J., Studts, J.L., \& Miller, T.W. (1998). Posttraumatic stress disorder after treatment for breast cancer: prevalence of diagnosis and use of the PTSD Checklist-Civilian Version (PCL-C) as a screening instrument. Journal of Consulting and Clinical Psychology, 66(3), pp. 586-590.

Andrykowski, M., Lykins, E., \& Floyd, A. (2008). Psychological health in cancer survivors. Seminar in Oncology Nursing, 24, pp. 193-201.

Azoulay, E., Pochard, F., Chevret, S., \& Adrie, C. (2004). Half the family members of intensive care unit patients do not want to share in the decision-making process: a study in 78 French intensive care units. Critical Care Medicine, 32, 1832-1838.

Azoulay, E., Pochard, F., Kentish-Barnes, N., Chevret, S. (2005). Risk of post-traumatic stress symptoms in family members of intensive care unit patients. American Journal of Respiratory and Critical Care Medicine, 171(9), pp. 987-94.

Barakat, L. P., Kazak, A. E., Meadows, A. T., Casey, R., Meeske, K., \& Stuber, M. L. (1997). Families surviving childhood cancer: A comparison of posttraumatic stress symptoms with families of healthy children. Journal of Pediatric Psychology, 22, pp. 843-859.

Bealle, L.S. (1997). Post-Traumatic Stress Disorder: A Bibliographic Essay. CHOICE, 34(6), pp. 917-930.

Berkman, L. F., Glass, T., Brissette, I., \& Seeman, T. E. (2000). From social integration to health: Durkheim in the new millennium. Social Science and Medicine, 51, pp. 843857.

Berkman, L. F., and Syme, S. L. (1979). Social networks, host resistance, and mortality: A nine-year follow-up study of Alameda county residents. American Journal of Epidemiology, 109, pp. 186-204.

Bisson, J. I. (2007). Post-traumatic stress disorder. Occupational Medicine, 57, pp. 399-403. 
Brandt, M. (2011). “What 9/11 has taught us about PTSD." Retrieved on 9/2/2011 fromhttp://scopeblog.stanford.edu/2011/09/what-911-has-taught-us-about-ptsd/

Brown, R., Madan-Swain, A., \& Lambert, R. (2003). Posttraumatic stress symptoms in adolescent survivors of childhood cancer and their mothers. Journal of Traumatic Stress, 16, pp. 309-318.

Bultz, B. D., \& Carlson, L. E. (2006). Emotional distress: The sixth vital sign - future directions in cancer care. Psychooncology, 15, pp. 93-95.

Burgess, C., Cornelius, V., Love, S., Graham, J., Richards, M., \& Ramirez, A. (2005). Depression and anxiety in women with early breast cancer: Five year observational cohort study. British Medical Journal, 330 (7493), pp. 1-4.

Burns, S. M., \& Mahalik, J. R. (2008). Sexual functioning as a moderator of the relationship between masculinity and men's adjustment following treatment for prostate cancer. American Journal of Men's Health, 2, pp. 6-16.

Butler, L.D., Field, N.P., Busch, A.L., Seplaki, J.E., Hastings, T.A., \& Spiegel, D. (2005). Anticipating loss and other temporal stressors predict traumatic stress symptoms among partners of metastatic/recurrent breast cancer patients. Psychooncology, 14(6), pp. 492-502.

Butler, L.D., Koopman, C., Classen, C., \& Spieger, D. (1999). Traumatic stress, life events, and emotional support in women with metastatic breast cancer: cancer-related traumatic stress symptoms associated with past and current stressors. Health Psychology, 18, pp. 555-560.

Cordova, M. J., Andrykowski, M. A., Kenady, D. E., McGrath, P. C., Sloan, D. A., \& Redd, W. H. (1995). Frequency and correlates of posttraumatic-stress-disorder-like symptoms after treatment for breast cancer. Journal of Consulting and Clinical Psychology, 63, pp. 981-986.

Cordova, M. J., Cunningham, L. L. C., Carlson, C. R., \& Andrykowski, M. A. (2001). Posttraumatic growth following breast cancer: A controlled comparison study. Health Psychology, 20, pp. 176-185.

Couper, J., Bloch, S., Love, A., Macvean, M., Duchesne, G. M., \& Kissane, D. (2006). Psychosocial adjustment of female partners of men with prostate cancer: A review of the literature. Psychooncology, 15, pp. 937-953.

Damber, J. E., \& Aus, G. (2008). Prostate cancer. Lancet, 371, pp. 1710-1721.

Dixon, D., Kilbourn, K., Cruess, S., Klimas, N., Fletcher, M. A., Ironson, G., Baum, A., Schneiderman, N., \& Antoni, M.H. (2001). Social support mediates the relationship between loneliness and Human Herpesvirus-Type 6 (HHV-6) antibody titers in HIV+ gay men following Hurricane Andrew. Journal of Applied Social Psychology, 31, pp. 1111-1132.

Elklit, A., Reinholt, N., Nielsen, L., Blum, A., \& Lasgaard, M. (2010). Posttraumatic stress disorder among bereaved relatives of cancer patients. Journal of Psychosocial Oncology, 28, pp. 399-412.

Epping-Jordan, J.E., Compas, B.E., \& Osowiecki, D. (1999). Psychological adjustment in breast cancer: process of emotional distress. Health Psychology, 18, pp. 315-326.

Foy, D. W., Resnick, H. S., Sipprelle, R. C., \& Carroll, E. M. (1987). Premilitary, military, and postmilitary factors in the development of combat-related posttraumatic stress disorder. Behavior Therapist, 10(1), pp. 3 - 9. 
Friedman, M.J. (1981). Post-Vietnam syndrome: Recognition and management. Psychosomatics, 22, pp. 931-942.

Friedman, M.J. (2006). Posttraumatic and acute stress disorders, Compact Clinicals, Kansas City, MO. Gandubert, C., Carriere, I., Escot,C., Soulier, M., Herme`s, A., Boulet, P., Ritchie, K., \& Chaudieu, I. (2009). Onset and relapse of psychiatric disorders following early breast cancer: a case-control study. Psycho-Oncology, 18, pp. 10291037.

Glanz K, Lerman C. 1992. Psychosocial impact of breast cancer: A critical review. Annals of Behavioral Medicine, 14, pp. 204-212.

Green, B.L., Rowland, J.H., Krupnick, J.L., Epstein, S.A., Stockton, P., Stern, N.M., Spertus I.L., \& Steakley, C. (1998). Prevalence of posttraumatic stress disorder in women with breast cancer. Psychosomatics, 39(2), pp. 102-111.

Gurevich, M., Devins, G.M., \& Rodin, G.M. (2002). Stress response syndromes and cancer. Psychosomatics, 43, pp. 259-281.

Gwede, C. K., Pow-Sang, J., Seigne, J., Heysek, R., Helal, M., Shade K., et al. (2005). Treatment decision-making strategies and influences in patients with localized prostate carcinoma. Cancer, 104, pp. 1381-1390.

Hamann, H., Somers, T.J., Smith, A.W., Inslicht, S.S., \& Baum, A. (2005). Posttraumatic stress associated with cancer history and BRCA1/2 genetic testing. Psychosomatic Medicine, 67, pp. 766-772.

Jacobsen, P.B., Sadler, I.J., Booth-Jones, M., Soety, E., Weitzner, M.A., \& Fields KK. (2002). Predictors ofposttraumatic stress disorder symptomatology following bone marrow transplantation for cancer. Journal of Consulting and Clinical Psychology, 70, pp. 235-240.

Jurbergs, N., Long, A., Ticona, L., \& Phipps, S. (2009). Symptoms of posttraumatic stress in parents of children with cancer: Are they elevated relative to parents of healthy children? Journal of Pediatric Psychology, 34, pp. 4-13.

Kangas, M., Henry, J.L., \& Bryant, R.A.(2002). Posttraumatic stress disorder following cancer. Clinical Psychology Review, 22, pp. 499-524.

Kangas, M., Henry, J.L., \& Bryant, R.A. (2005). Predictors of posttraumatic stress disorder following cancer. Health Psychology, 24(6), pp. 579-585.

Kazak, A.E. (1998). Posttraumatic distress in childhood cancer survivors and their parents. Medical and Pediatric Oncology (supplement), 1, pp. 60-68.

Kazak, A. (2005). Evidence-based interventions for survivors of childhood cancer and their families. Journal of Pediatric Psychology, 30(1), pp. 29-39.

Kazak, A.E., Alderfer, M., Rourke, M.T., Simms, S., Streisand, R., \& Grossman, J.R. (2004). Posttraumatic stress disorder (PTSD) and posttraumatic stress symptoms (PTSS) in families of adolescent childhood cancer survivors. Journal of Pediatric Psychology, 29, pp. 211-219.

Kazak, A. E., Barakat, L. P., Meeske, K., Christakis, D., Meadows, A. T., \& Casey, R. (1997). Posttraumatic stress, family functioning, and social support in survivors of childhood leukemia and their mothers and fathers. Journal of Consulting and Clinical Psychology, 65, pp. 120-129.

Kazak, A.E., Boeving, C.A., Alderfer, M.A., Hwang, W.T., \& Reilly, A. (2005). Posttraumatic stress symptoms during treatment in parents of children with cancer. Journal of Clinical Oncology, 23, pp. 7405-7410. 
Kronenwetter, C., Weidner, G., Pettengill, E., Marlin, R., Crutchfield, L., McCormac, P., et al. (2005). A qualitativeanalysis of interviews of men with early stage prostate cancer: The Prostate Cancer Lifestyle Trial. Cancer Nursing, 28, pp. 99-107.

Kwekkeboom, K.L., \& Seng, J.S. (2002). Recognizing and responding to post-traumatic stress disorder in people with cancer. Oncology Nursing Forum, 29(4), pp. 643-650.

Landolt, M.A., Boehler, U., Schwager, C., Schallberger, U., \& Nuessli, R. (1998). Posttraumatic stress disorder in paediatric patients and their parents: an exploratory study. Journal of Paediatrics and Child Health, 34(6), pp. 539-543.

Lewis, J., Manne, S., DuHamel, K., Johnson, S., Bovbjerg, D., Currie, V., Winkel, G., Redd, W. (2001). Social Support, Intrusive Thoughts, and Quality of Life in Breast Cancer Survivors. Journal of Behavioral Medicine, 24, pp. 231-245.

Luecken, L.J., Dausch, B., Gulla, V., Hong, R., \& Compas' B. (2004). Alterations in morning cortisol associated with PTSD in women with breast cancer. Journal of Psychosomatic Research, 56, pp. 13-15.

Ljungman, G., McGrath, P., Cooper, E., Widger, K., Cecolini, J., Fernandez, C., Wilkins, K. (2003). Psychosocial needs of families with a child with cancer. Journal of Pediatric Hematology-Oncology, 25(3), pp. 223-231.

Lutgendorf, S. K., Sood, A. K., Anderson, B., McGinn, S., Maiseri, H., Dao, M., Sorosky, J. I., Geest, K. D., Ritchie, J., \& Lubaroff, D. M. (2005). Social support, psychological distress, and natural killer cell activity in ovarian cancer. Journal of Clinical Oncology, 23, pp. 7105-7113.

Manne, S., DuHamel, K., \& Ostroff, J. (2004). Anxiety, depressive, and posttraumatic stress disorders among mothers of pediatric hematopoietic stem cell transplantation. Pediatrics 113, pp. 1700-1708.

McGrath, P. (2001). Findings of the impact of treatment for childhood acute lymphoblastic leukaemia on family relationships. Child and Family Social Work, 6, pp. 229-237.

Mehnert, A., \& Koch, U. (2007). Prevalence of acute and post-traumatic stress disorder and comorbid mental disorders in breast cancer patients during primary cancer care: a prospective study. Psychooncology,16(3), pp. 181-188.

Mezey, G., \& Robbins, I. (2001). Usefulness and validity of post-traumatic stress disorder as a psychiatric category. British Medical Journal, 323(7312, pp. :561-563.

Montgomery, C., Pocock, M., Titley, K., \& Lloyd, K. (2003). Predicting psychological distress in patients with leukaemia and lymphoma. Journal of Psychosomatic Research, 54(4), pp. 289-292.

Mosher, C. E., \& Danoff-Burg, S. (2005). Psychosocial impact of parental cancer in adulthood: A conceptual and empirical review. Clinical Psychology Review, 25, pp. 365-382.

Mundy, E. A., Blanchard, E. B., Cirenza, E., Gargiulo, J., Maloy, B., \& Blanchard, C. G., (2000). Posttraumatic stress disorder in breast cancer patients following autologous bone marrow transplantation or conventional cancer treatments. Behaviour Research $\mathcal{E}$ Therapy, 38, pp. 1015-1027.

Namiki, S., Saito, S., Tochigi, T., Numata, I., Ioritani, N., \& Arai, Y. (2007). Psychological distress in Japanese men with localized prostate cancer. International Journal of Urology, 14, pp. 924-929.

Nolbris, M., Enskar, K., \& Hellstrom, A. (2007). Experience of siblings of children treated for cancer. European Journal of Oncology Nursing, 22, pp. 227-233. 
Okamura, M., Yamawaki, S., Akechi, T., Taniguchi, K., \& Uchitomi, Y. (2005). Psychiatric disorders following first breast cancer recurrence: prevalence, associated factors and relationship to quality of life. Japanese Journal of Clinical Oncology 35(6), pp. 302309.

Packman, W.L., Fine, J., Chesterman, B., van Zutphen, K., Golan, R., Amylon, M. (2004).Camp Okizu: Preliminary investigation of a psychological intervention for siblings of pediatric cancer patients. Children's Health Care, 33, pp. 201-215.

Palmer, S.C., Kagee, A., Coyne, J.C., \& DeMichele, A. (2004). Experience of trauma, distress, and posttraumatic stress disorder among breast cancer patients. Psychosomatic Medicine, 66(2), pp. 258-264.

Patterson, J.M., Holm, K.E., \& Gurney, J.G. (2004). The impact of childhood cancer on the family: A qualitative analysis of strains, resources, and coping behaviors. Psychooncology, 13, pp. 390-407.

Pelcovitz, D., Libov, B.G., Mandel, F., Kaplan, S., Weinblatt, M., \& Septimus, A. (1998). Posttraumatic stress disorder and family functioning in adolescent cancer. Journal of Traumatic Stress, 11(2), pp. 205-221.

Penson, D. F. (2007). Quality of life after therapy for localized prostate cancer. Cancer Journal, 13, pp. 318-326.

Perez, M. A., Skinner, E. C., \& Meyerowitz, B. E. (2002). Sexuality and intimacy following radical prostatectomy: Patientand partner perspectives. Health Psychology, 21, pp. 288-293.

Poder, U., Ljungman, G., \& von Essen, L. (2008). Posttraumatic stress disorder among parents of children on cancer treatment: a longitudinal study. Psychooncology, 17, pp. $430-437$.

Ries, L., Melbert, D., Krapcho, M., Stinchcomb, D.G., Howlader, N., \& Horner, M.J. (Eds.) SEER cancer statistics review, 1975-2005. Retrieved 8/1/08 from http://seer.cancer.gov/csr/1975_2005/

Sanda, M. G., Dunn, R. L., Michalski, J., Sandler, H. M., Northouse, L., Hembroff, L., et al. (2008). Quality of life andsatisfaction with outcome among prostate-cancer survivors. New England Journal of Medicine, 358, pp. 1250-1261.

Schuster, M.A. Stein, B.D., Jaycox, L.H., Collins, R.L., Marshall, G.N., Elliott, M.N., Zhou, A.J., Kanouse, D.E., Morrison, J.L., \& Berry, S.H. (2001). A national survey of stress reactions after the September 11, 2001, terrorist attacks. New England Journal of Medicine, 345( 20), pp. 1507-1512.

Segman, R.H., Shefi, N., Goltser-Dubner, T., Friedman, N., Kaminski, N., \& Shalev, A.Y. (2005). Peripheral blood mononuclear cell gene expression profiles identify emergent post-traumatic stress disorder among trauma survivors. Molecular Psychiatry,10, pp. 500-513.

Shapiro, S. L., Lopez, A. M., Schwartz, G. E., Bootzin, R., Figueredo, A. J., Braden, C. J., et al. (2001). Quality of life and breast cancer: Relationship to psychosocial variables. Journal of Clinical Psychology, 57(4), pp. 501-519.

Shay, J. (1994). Achilles in Vietnam: Combat Trauma and the Undoing of Character, Maxwell Macmillan, New York.

Shelby, R., Golden-Kreutz, D., \& Andersen, B. (2008). PTSD diagnoses, subsyndromal symptoms, and comorbidities contribute to impairments for breast cancer survivors. Journal of Traumatic Stress, 21, pp. 165-172. 
Steginga, S. K., Ferguson, M., Clutton, S., Gardiner, R. A., \& Nicol, D. (2008). Early decision and psychosocial support intervention for men with localised prostate cancer: An integrated approach. Supportive Care in Cancer, 16, pp. 821-829.

Steginga, S. K., Occhipinti, S., Gardiner, R. A., Yaxley, J., \& Heathcote, P. (2004). Prospective study of men's psychological and decision-related adjustment after treatment for localized prostate cancer. Urology, 63, pp. 751-756.

Stoppelbein, L., \& Greening, L. (2007). The risk of posttraumatic stress disorder in mothers of children diagnosed with pediatric cancer and type I diabetes. Journal of Pediatric Psychology 32, pp. 223-229.

Tuinmann, M. A., Fleer, J., Hoekstra, H. J., Sleijfer, D. T., \& Hoekstra-Weebers, J. (2004). Quality of life and stress response symptoms in long-term and recent spouses of testicular cancer survivors. European Journal of Cancer, 40, pp. 1696-1703.

Uchino, B. N. (2004). Social support and physical health: Understanding the health consequences of relationships, Yale University Press, New Haven, CT.

Uchino, B.N., Cacioppo, J.T., \& Kiecolt-Glaser, K.G. (1996). The relationships between social support and physiological processes: A review with emphasis on underlying mechanisms and implications for health. Psychological Bulletin, 119, pp. 488-531.

Uddin, M., Aiello, A.E., Wildman, D.E., Koenen, K.C., Pawelec, G., de Los Santos, R., Goldmann, E., \& Galea, S. (2010). Epigenetic and immune function profiles associated with posttraumatic stress disorder. Proceedings of the National Academy of Sciences, 107, pp. 9470-9475.

Vos, P. J., Garssen, B., Visser, A. P., Duivenvoorden, H. J., \& de Haes, H. C. J. M. (2004). Early stage breast cancer: explaining level of psychosocial adjustment using structural equation modeling. Journal of Behavioral Medicine, 27(6), pp. 557-580.

Widows, M.R., Jacobsen, P.B., \& Fields, K.K. (2000). Relation of psychological vulnerability factors to posttraumatic stress disorder symptomatology in bone marrow transplant recipients. Psychosomatic Medicine, 62, pp. 873-882.

Wong, C.M. (2002) Post-traumatic stress disorder: Advances in psychoneuroimmunology. Psychiatric Clinics of North America, 25, pp. 369-383.

Woodgate, R.L. (2006). Siblings' experiences with childhood cancer. Cancer Nursing 29, pp. 406-414.

Yehuda, R., Cai, G., Golier, J.A., Sarapas, C., Galea, S., Ising, M., Rein, T., Schmeidler, J., Müller-Myhsok, B., Holsboer, F., \& Buxbaum, J.D. (2009). Gene expression patterns associated with posttraumatic stress disorder following exposure to the World Trade Center attacks. Biological Psychiatry, 66, pp. 708-711.

Yehuda, R., \& LeDoux, J. (2007) Response variation following trauma: A translational neuroscience approach to understanding PTSD. Neuron, 56, pp. 19-32.

Zieker, J., Zieker, D., Jatzko, A., Dietzsch, J., Nieselt, K., Schmitt, A., Bertsch, T., Fassbender, K., Spanagel, R., Northoff, H., \& Gebicke-Haerter, P.J. (2007) Differential gene expression in peripheral blood of patients suffering from post-traumatic stress disorder. Molecular Psychiatry, 12, pp. 116-118.

Zisook, S., Chentsova-Dutton, Y., \& Shuchter, S.R. (1998). PTSD following bereavement. Annals of Clinical Psychiatry, 10, pp. 157-63. 


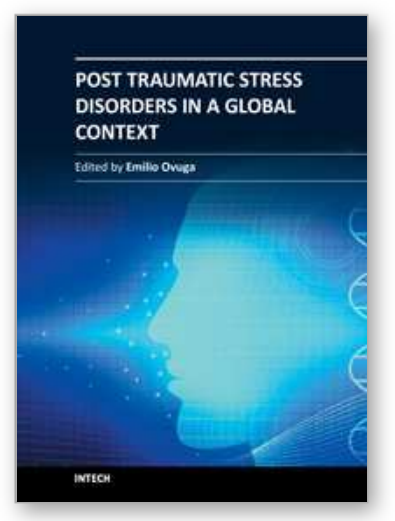

\author{
Post Traumatic Stress Disorders in a Global Context \\ Edited by Prof. Emilio Ovuga, Md, PhD
}

ISBN 978-953-307-825-0

Hard cover, 286 pages

Publisher InTech

Published online 20, January, 2012

Published in print edition January, 2012

If, as a health care or social service provider, one was called upon to help someone who has experienced terror in the hands of a hostage taker, an irate and chronically abusive spouse or parent, or a has survived a motor vehicle accident, landslide, earthquake, hurricane or even a massive flood, what would be one's priority response? What would be considered as the most pressing need of the individual requiring care? Whatever the answer to each of these questions, people who have experienced terror, suffer considerable psychological injury. Post-Traumatic Stress Disorder in a Global Context offers some answers to meet the needs of health care and socials service providers in all settings, whether in a hospital emergency room, at the war front, or natural disaster site. The take home message is, after providing emergency care, there is always a pressing need to provide mental health care to all victims of traumatic stress.

\title{
How to reference
}

In order to correctly reference this scholarly work, feel free to copy and paste the following:

A.M. Tacón (2012). PTSD in the Context of Malignant Disease, Post Traumatic Stress Disorders in a Global Context, Prof. Emilio Ovuga, Md, PhD (Ed.), ISBN: 978-953-307-825-0, InTech, Available from: http://www.intechopen.com/books/post-traumatic-stress-disorders-in-a-global-context/ptsd-in-the-context-ofmalignant-disease

\section{INTECH}

open science | open minds

\author{
InTech Europe \\ University Campus STeP Ri \\ Slavka Krautzeka 83/A \\ 51000 Rijeka, Croatia \\ Phone: +385 (51) 770447 \\ Fax: +385 (51) 686166 \\ www.intechopen.com
}

\author{
InTech China \\ Unit 405, Office Block, Hotel Equatorial Shanghai \\ No.65, Yan An Road (West), Shanghai, 200040, China \\ 中国上海市延安西路65号上海国际贵都大饭店办公楼 405 单元 \\ Phone: +86-21-62489820 \\ Fax: +86-21-62489821
}


(C) 2012 The Author(s). Licensee IntechOpen. This is an open access article distributed under the terms of the Creative Commons Attribution 3.0 License, which permits unrestricted use, distribution, and reproduction in any medium, provided the original work is properly cited. 